\title{
Water characteristics of the Western side along the Gulf of Suez (Red Sea) during (2014-2015)
}

\author{
Mohamed A. Hamed"; Nadia A. El-Agroudy ${ }^{1}$; Abd Allah E. Ali ${ }^{2}$ \\ and Heba M. Ezz El-Din ${ }^{1}$
}

1- National Institute of Oceanography and Fisheries, Suez, Egypt

2- Suez Canal University, Faculty of Science, Marine Science Department

\begin{abstract}
Physico-chemical parameters and nutrient salts were determined seasonally in water samples collected from 14 stations along the western side of the Gulf of Suez during the period from spring 2014 to winter 2015. The results indicated that, the annual mean range for the surface water samples collected from the north-western sector of the study area (water temperature, salinity, $\mathrm{pH}$, dissolved oxygen, biological oxygen demand, nitrite, nitrate, ammonia and dissolved inorganic phosphate) were $18.40-30.10^{\circ} \mathrm{C}, 39.90-40.51 \% 0,8.08$ 8.39, 4.28-10.41 $\mathrm{mgO}_{2} \mathrm{~L}^{-1}, 1.53-7.04 \mathrm{mgO}_{2} \mathrm{~L}^{-1}, 0.77-2.82 \mu \mathrm{molL}^{-1}, 2.07-67.88 \mu \mathrm{molL}^{-1}, 3.24-$ $43.15 \mu \mathrm{molL}^{-1}$ and $0.93-3.45 \mu \mathrm{molL}^{-1}$, respectively. The corresponding values for surface water samples collected from the south-western sector of the study area were $17.70-33.30^{\circ} \mathrm{C}$, 40.45-40.88\%o, 8.16-8.37, 4.36-10.71 $\mathrm{mgO}_{2} \mathrm{~L}^{-1}, 1.53-6.73 \mathrm{mgO}_{2} \mathrm{~L}^{-1}, 1.12-2.53 \mu \mathrm{molL}^{-1}$, 5.27$11.48 \mu \mathrm{molL}^{-1}, 1.94-10.80 \mu \mathrm{molL}^{-1}$ and $1.87-4.77 \mu \mathrm{molL}^{-1}$, respectively.

Generally, the present data indicated that the concentration of the measured Physicochemical parameters were relatively high especially (the level of nutrient salts) at the northwestern of the Gulf and decreased southward (Red Sea). This reflects high intensive disposal of sewage and industrial effluents in the north-western sector of the Gulf of Suez.

Seasonally, nutrient salts levels increased during spring and summer which may be attributed to increased human and industrial activities and disposal of treated and untreated sewage. Nutrient salts decreased during autumn, except for phosphate.

The annual average of N:P ratio was 10.83 for surface water samples in the northwestern sector, while it was 4.68 in the south-western sector of the Gulf of Suez. The results of N:P ratio indicated that the north-western sector of the Gulf of Suez is in the eutrophic state, mainly due to the high load of nitrogenous compounds especially ammonia.

Results of the present study reflect that the north-western sector of study area adverse from high intensive disposal of sewage and industrial effluents.
\end{abstract}

Keywords: Physico-chemical parameters, nutrient salts, and the Gulf of Suez.

\section{INTRODUCTION}

Water quality criteria is not only intended to protect essential and significant life in water, as well as the direct users of water, but also to protect life that is dependent in water for its existence, or that may consume intentionally any edible portion of such life. Also, the assessment of physico-chemical parameters and nutrients (water quality) are one of the most important indicators for the extent of pollution in the marine environment. The problems of sewage pollution of the Gulf of Suez waters have become a point of local concern. Signs of this kind of pollution have already been observed in the last few years along the coast of the Suez Gulf (Soliman, 1999). The disposal of untreated sewage may be harmful concerning its possible hygienic and aesthetical effects and its impact on fauna and flora in the marine environment.

The hydrography and chemistry of the Suez Gulf were studied by several authors Hamed and Said, (2000) and Fahmy et al., (2005). The nutrient salts concentrations in the 
Mohamed A. Hamed et al.

Gulf of Suez increase gradually from the south to north (Hamed, 1996). So the relation between human activities and environmental changes in the Gulf of Suez require knowledge of trends in water characteristics. The Gulf of Suez is one of arms of Sinai Pensiula. It is located in the northwest of the Red Sea. The geographical position of the Gulf of Suez makes it an important shipping route for oil tankers in the Middle East. It extends from Port-tawfik in north in Suez City to Gemsa in south, with overall length $280 \mathrm{~km}$., width (20-40) km. and $45 \mathrm{~m}$. water depth (Beltegy, 1983). The aim of this work is to evaluate the levels of some physic-chemical parameters and nutrient salts in water samples collected along the western side of the Gulf of Suez.

\section{MATERIALS AND METHODS}

\section{Description of the study area}

The western side of the Gulf of Suez was divided into two sectors (Fig. 1).

Sector A (Northwestern sector): its water is mainly affected by industrial and domestic wastes. It is represented by stations (I: Port-tawfik, II: El-Zaiytia, III: El-Kabanon, IV: Attaka, V: El-Adabyia, VI: Green Island, VII: Petroget and VIII: El-Sokhna).

Sector B (Southwestern sector): its water is mainly affected by different petroleum activities. It is represented by stations (IX: El-Zafrana, X: RasBakr, XI:RasGharib, XII:RasShoker, XIII:Gebl El-Zeet and XIV:Gemsa).

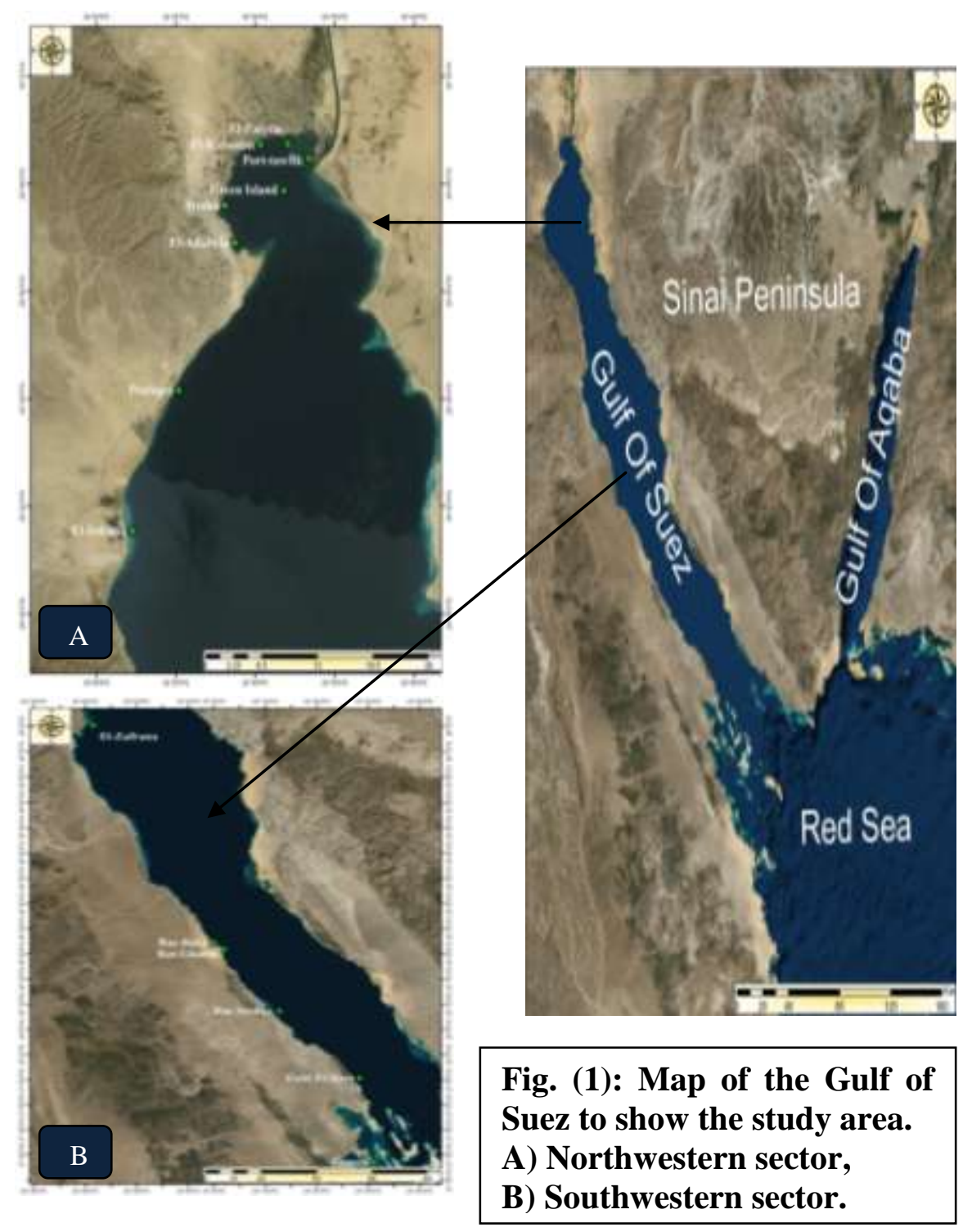




\section{Water characteristics of the Western side along the Gulf of Suez (Red Sea) during (2014-2015)}

\section{Samples collection and storage}

Water samples were collected seasonally through spring, summer, autumn of 2014 and winter 2015. Water temperature was measured by using a simple pocket thermometer graduated to $0.1{ }^{0} \mathrm{C}$. The $\mathrm{pH}$ value of water samples were determined by using portable $\mathrm{pH}$ meter (Orion model 210 digital). Salinity was determined using salinometer (model YSI 33). Dissolved oxygen and biological oxygen demand (BOD) were measured according to (APHA, 2005). The dissolved nutrients salts were analyzed immediately in water samples. Nitrite, nitrate, ammonia and dissolved inorganic phosphorous were measured spectrophotometrically according to the method described by Parsons et al. (1984) by using US-visible single beam spectrophotometer (Beckman model DU6).

\section{Physico-chemical parameters}

\section{RESULTS AND DISCUSSION}

In the present study, the highest mean temperature $\left(30.10-33.30{ }^{\circ} \mathrm{C}\right)$ was found at St.IV and St.XIV (Attaka and Gemsa), while the lowest value $\left(18.40-17.70^{\circ} \mathrm{C}\right)$ was found at St. II and St.X (El-Zaiytia and RasBakr) (Tables $1 \& 2$ ). Generally, the maximum mean value was recorded in summer and the minimum one was recorded in winter. These variations in water temperature mainly depended on weather conditions (solar radiations, wind, wave, water circulation and seasonal changes in air temperature) and partially on the time of sampling (Khalil et al., 2014).

Salinity showed a narrow range of variations between stations (Tables $1 \& 2$ ) and (Fig. 2). Generally, the results indicated that, salinity increases from southward to northward, where it ranged between (39.90-40.51\%o) at St. III and St. II (El-Kabanon and El-Zaiytia) at the northwestern sector, this is probably due to the disposal of the treated and untreated sewage and industrial effluents from the nearby factories. It fluctuated between (40.45-40.88) at St.IX and St.XIV (El-Zafrana and Gemsa). The results indicated that the salinity of water reached its maximum during (warm season) summer and the minimum during (cold season) winter. This may be attributed to evaporation of water by elevation of temperature. Evaporation must be considered as one of the most controlling factors for salinity and consequently density, circulation and sea level variation (Maiyza, 1988).

$\mathrm{pH}$ is of the vital environmental characteristics for the survival, metabolism, physiology, growth of aquatic organisms and chemical processes (Ramanathan et al., 2005). The values of $\mathrm{pH}$ varied within narrow limit as shown in Tables $(1 \& 2)$ and Figure (2). On the northwestern sector, the mean values of $\mathrm{pH}$ ranged between (8.08-8.39) at St. III and St.VI (El-Kabanon and Green Island), this is may be related to the fact that this location is affecting by disposal of treated and untreated sewage and industrial effluents from the nearby factories, and the minimum $\mathrm{pH}$ value was recorded in location far away of any pollution sources. Also, it differentiated between (8.16-8.37) at St.X and St.XII (Ras Bakr and Ras Shoker). Annually, the highest mean $\mathrm{pH}$ (8.36) was found at Ras Shoker and the lowest one (8.12) was recorded at Green Island. Relatively the higher $\mathrm{pH}$ values were recorded during summer (8.35) in which the rise in temperature usually causing more consumption of carbon dioxide due to the phytoplankton photosynthetic activity. On the other hand, lower $\mathrm{pH}$ values were observed during winter (8.11) in which there is an increasing in $\mathrm{CO}_{2}$ level due to increasing of the rate of organic matter decomposition by the microbial respiration.

Tables ( $1 \& 2$ ) and Figure (2) presented the mean concentrations of DO in water samples collected from the western sector of the Gulf of Suez. On the northwestern sector, the fluctuations of DO content varied between (4.28-10.41 $\mathrm{mgO}_{2} \mathrm{~L}^{-1}$ ) at St.III and St.IV (ElKabanon and Attaka), this may be due to increased disposal of untreated sewage from Suez City. On the other sector, the levels of DO content ranged between $\left(4.36-10.71 \mathrm{mgO}_{2} \mathrm{~L}^{-1}\right)$ at 
Mohamed A. Hamed et al.

St.XII and St.XIII (Ras Shoker and Gebl El-Zeet). Annually, the highest mean DO $\left(7.97 \mathrm{mgO}_{2} \mathrm{~L}^{-1}\right)$ was recorded at Gebl El-Zeet and the lowest one $\left(5.89 \mathrm{mgO}_{2} \mathrm{~L}^{-1}\right)$ at Porttawfik. Seasonally, the maximum mean recorded $\mathrm{DO}\left(9.08 \mathrm{mgO}_{2} \mathrm{~L}^{-1}\right)$ was during winter and the minimum (4.76 $\left.\mathrm{mgO}_{2} \mathrm{~L}^{-1}\right)$ was during summer. The above mentioned results indicated that, the dissolved oxygen values increased during winter, this probably attributed to activities of air movement allowing more transfer of oxygen across the air-water interface and active water mixing and gas exchange (Hamed et al., 2012), while it decreased during summer, this is may be due to increased human activities and disposal of untreated sewage. This high oxygen content indicates a good mixing in the water column especially during winter (Girgis, 1980). This may be attributed to the increase of temperature during the summer, which causes decreasing in the degree of solubility of atmospheric oxygen gas and due to the increase in oxygen consumption during decomposition of organic matters and the oxidation of chemicals from effluents of different sources (Cole, 1979). In the present study, the results agree with result reported by UNESCO/WHO (1973), where the coastal waters require minimum value of oxygen $4.0 \mathrm{mgO}_{2} \mathrm{~L}^{-1}$ and it will be better with $5.0 \mathrm{mgO}_{2} \mathrm{~L}^{-1}$ for optimum ecosystem function.

In the present study BOD showed a wide range of variations as shown in Tables $(1 \&$ 2) and Figure (2). The highest mean value recorded $\left(7.04 \mathrm{mgO}_{2} \mathrm{~L}^{-1}\right)$ was at St.III (El-Kabanon), this is due to increase of human activities and disposal of untreated sewage from Suez City. Also, the lowest mean recorded $\left(1.23 \mathrm{mgO}_{2} \mathrm{~L}^{-1}\right)$ was at St.VIII (El-Sokhna). On the other hand, BOD ranged between the maximum level $\left(6.73 \mathrm{mgO}_{2} \mathrm{~L}^{-1}\right)$ observed at St.XIII (Gebl El-Zeet) and the minimum level $\left(1.53 \mathrm{mgO}_{2} \mathrm{~L}^{-1}\right)$ observed at St.IX (El-Zafrana). The maximum annual recorded $\left(4.94 \mathrm{mgO}_{2} \mathrm{~L}^{-1}\right)$ was at Petroget, while the minimum one $\left(2.49 \mathrm{mgO}_{2} \mathrm{~L}^{-1}\right)$ was at Green Island. Seasonally, the highest mean BOD (4.58 $\mathrm{mgO}_{2} \mathrm{~L}^{-1}$ ) was during summer season, due to increased flourishing of phytoplankton and photosynthesis activity, increased human activities and extensive disposal of treated and untreated sewage and discharge of industrial effluents (Khalil et al., 2011). On the other hand, the lowest mean $\left(3.13 \mathrm{mgO}_{2} \mathrm{~L}^{-1}\right)$ was during spring season, this may be attributed to decrease temperature slightly and related to the basis of low activity of microorganisms during cold season (Emara et al., 2013). While, seasonal BOD means varied between (2.08 and $4.44 \mathrm{mgO}_{2} \mathrm{~L}^{-1}$ ) at summer and autumn seasons, respectively. The BOD of the Gulf is slightly high indicating the presence of load of disposal of sewage, agriculture, industrial and petrochemical effluents. In the present study, the results of BOD comparable with other recorded by Anon (1975) except El-Kabanon which recorded relatively high levels, this is may be due to increased human activities and disposal of treated and untreated sewage from Suez City. 
Table (1): Mean concentrations of physico-chemical parameters in water samples collected from the Western sector of the Gulf of Suez during spring and summer (2014).

\begin{tabular}{|c|c|c|c|c|c|c|c|c|c|c|}
\hline \multicolumn{11}{|c|}{ Seasons } \\
\hline \multirow[b]{2}{*}{ St. } & \multicolumn{5}{|c|}{ Spring (2014) } & \multicolumn{5}{|c|}{ Summer (2014) } \\
\hline & $\mathbf{T ~ C ~}^{0}$ & S\% 0 & pH & $\begin{array}{c}\mathrm{DO} \\
\mathrm{mgO}_{2} \mathrm{~L}^{-1}\end{array}$ & $\begin{array}{c}\mathrm{BOD} \\
\mathrm{mgO}_{2} \mathbf{L}^{-1}\end{array}$ & T C $^{0}$ & S\%o & pH & $\begin{array}{c}\mathrm{DO} \\
\mathrm{mgO}_{2} \mathrm{~L}^{-1}\end{array}$ & $\begin{array}{c}\mathrm{BOD} \\
\mathrm{mgO}_{2} \mathrm{~L}^{-1}\end{array}$ \\
\hline I & 23.70 & 40.39 & 8.21 & 4.44 & 2.60 & 29.40 & 40.40 & 8.29 & 4.74 & 2.14 \\
\hline II & 23.40 & 40.50 & 8.24 & 7.65 & 4.44 & 29.30 & 40.52 & 8.21 & 4.99 & 1.68 \\
\hline III & 23.80 & 39.91 & 8.18 & 5.51 & 7.04 & 29.60 & 39.99 & 8.39 & 4.28 & 4.74 \\
\hline IV & 24.50 & 40.19 & 8.19 & 9.18 & 3.06 & 30.10 & 40.20 & 8.22 & 4.89 & 4.13 \\
\hline $\mathrm{V}$ & 24.90 & 40.31 & 8.25 & 7.65 & 6.27 & 29.90 & 40.33 & 8.22 & 4.74 & 5.20 \\
\hline VI & 23.80 & 40.22 & 8.10 & 7.71 & 3.67 & 29 & 40.28 & 8.20 & 4.88 & 3.21 \\
\hline VII & 24.90 & 40.0 & 8.22 & 7.36 & 5.97 & 30 & 40.08 & 8.30 & 6.27 & 4.44 \\
\hline VIII & 25.50 & 40.19 & 8.18 & 7.19 & 5.51 & 29.90 & 40.28 & 8.23 & 4.89 & 5.82 \\
\hline IX & 28.10 & 40.49 & 8.36 & 6.89 & 2.45 & 27 & 40.57 & 8.33 & 5.06 & 1.53 \\
\hline$X$ & 28.70 & 40.60 & 8.22 & 7.35 & 2.14 & 27.60 & 40.64 & 8.25 & 6.11 & 1.99 \\
\hline $\mathrm{XI}$ & 26.50 & 40.70 & 8.33 & 5.35 & 2.29 & 29 & 40.74 & 8.35 & 4.99 & 2.11 \\
\hline XII & 28.10 & 40.69 & 8.37 & 5.67 & 1.99 & 30.80 & 40.75 & 8.37 & 4.36 & 2.14 \\
\hline XIII & 28.20 & 40.80 & 8.28 & 6.87 & 2.75 & 30.50 & 40.86 & 8.31 & 5.11 & 1.68 \\
\hline VIX & 27.10 & 40.81 & 8.32 & 5.39 & 3.99 & 33.30 & 40.88 & 8.36 & 5.14 & 3.06 \\
\hline
\end{tabular}

Table (2): Mean concentrations of physico-chemical parameters in water samples collected from the Western sector of the Gulf of Suez during autumn (2014) and winter (2015).

\begin{tabular}{|c|c|c|c|c|c|c|c|c|c|c|}
\hline \multicolumn{11}{|c|}{ Seasons } \\
\hline \multirow{2}{*}{$\begin{array}{r}\text { P. } \\
\text { St. }\end{array}$} & \multicolumn{5}{|c|}{ Autumn (2014) } & \multicolumn{5}{|c|}{ Winter (2015) } \\
\hline & $\mathbf{T ~ C ~}^{0}$ & S\%o & pH & $\begin{array}{c}\mathrm{DO} \\
\mathrm{mgO}_{2} \mathrm{~L}^{-1}\end{array}$ & $\begin{array}{c}\mathrm{BOD} \\
\mathrm{mgO}_{2} \mathrm{~L}^{-1}\end{array}$ & T C $^{0}$ & S\%o & pH & $\begin{array}{c}\mathrm{DO} \\
\mathrm{mgO}_{2} \mathrm{~L}^{-1}\end{array}$ & $\underset{\mathrm{mgO}_{2} \mathrm{~L}^{-1}}{\mathrm{BOD}}$ \\
\hline $\mathrm{I}$ & 23.90 & 40.39 & 8.16 & 4.89 & 1.53 & 18.70 & 40.35 & 8.14 & 9.95 & 4.44 \\
\hline II & 23.50 & 40.51 & 8.17 & 4.67 & 2.29 & 18.40 & 40.49 & 8.12 & 8.42 & 1.98 \\
\hline III & 23.90 & 39.92 & 8.18 & 5.51 & 3.21 & 18.50 & 39.90 & 8.15 & 8.42 & 6.58 \\
\hline IV & 24.40 & 40.18 & 8.17 & 5.51 & 1.38 & 19 & 40.18 & 8.16 & 10.41 & 3.98 \\
\hline $\mathrm{V}$ & 25.20 & 40.30 & 8.18 & 5.82 & 1.53 & 18.50 & 40.29 & 8.10 & 8.11 & 3.98 \\
\hline VI & 24.10 & 40.23 & 8.15 & 4.44 & 1.53 & 18.70 & 40.20 & 8.08 & 8.87 & 2.44 \\
\hline VII & 24.10 & 40.02 & 8.14 & 7.35 & 3.06 & 18.70 & 39.99 & 8.16 & 9.79 & 6.25 \\
\hline VIII & 24 & 40.23 & 8.15 & 8.26 & 1.53 & 18.80 & 40.17 & 8.13 & 8.72 & 5.51 \\
\hline IX & 22.10 & 40.51 & 8.32 & 6.36 & 4.67 & 18.10 & 40.45 & 8.30 & 7.59 & 2.91 \\
\hline$X$ & 22.80 & 40.61 & 8.20 & 7.56 & 4.44 & 17.70 & 40.58 & 8.16 & 8.42 & 2.91 \\
\hline XI & 22.70 & 40.69 & 8.30 & 6.89 & 2.91 & 17.90 & 40.66 & 8.29 & 7.89 & 4.44 \\
\hline XII & 22.30 & 40.71 & 8.33 & 7.18 & 5.20 & 17.90 & 40.67 & 8.32 & 8.32 & 3.67 \\
\hline XIII & 23.40 & 40.81 & 8.29 & 9.18 & 5.97 & 18 & 40.78 & 8.25 & 10.71 & 6.73 \\
\hline VIX & 22.60 & 40.82 & 8.31 & 5.59 & 4.44 & 17.90 & 40.80 & 8.29 & 7.85 & 5.20 \\
\hline
\end{tabular}


Mohamed A. Hamed et al.

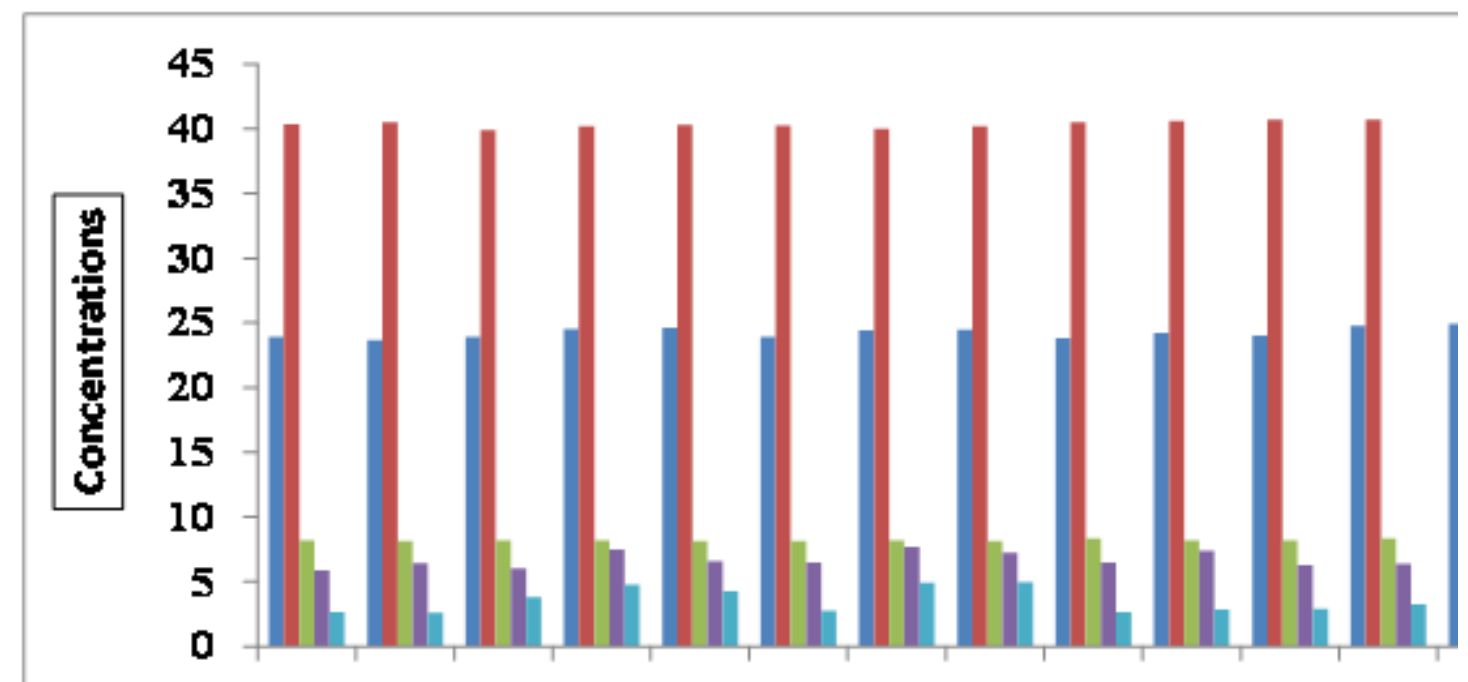

Fig. (2): Annual mean concentrations of physico-chemical parameters of water samples collected from the western sector of the Gulf of Suez.

\section{Nutrient salts}

Tables (3 \& 4) and Figure (3) showed the mean concentrations of nutrient salts $\left(\mu \mathrm{molL}^{-1}\right)$ in water samples collected from the western sector of the Gulf of Suez. Nitrite fluctuated between the maximum mean values $\left(2.82 \mu \mathrm{molL}^{-1}\right)$ recorded at St.V at ElAdabyia, this is may be attributed to increase human activities mainly from domestic drainage and shipping activities, while the minimum mean value $\left(0.77 \mu \mathrm{molL}^{-1}\right)$ was recorded at St.II (El-Zaiytia). This is probably due to its instability; it is oxidized to nitrate or ammonia, by both chemical reaction and / or biological by bacteria (Barakat et al., 2009). Also, nitrite values varied between the highest value $\left(2.53 \mu \mathrm{molL}^{-1}\right)$ observed at St.VIX (Gemsa) and the lowest value $\left(1.12 \mu \mathrm{molL}^{-1}\right)$ observed at St.XIII (Gebl El-Zeet).The maximum annual mean was recorded $\left(2.31 \mu \mathrm{molL}^{-1}\right)$ at Gemsa, while the minimum value $\left(1.48 \mu \mathrm{molL}^{-1}\right)$ was at Petroget. Also, the highest seasonal mean was recorded $\left(2.51 \mu \mathrm{molL}^{-1}\right)$ during spring season and the minimum one $\left(1.45 \mu \mathrm{molL}^{-1}\right)$ was during autumn season. This is may be to increased different human and shipping activities during warm season. This result agrees with that of Hamed et al. (2010).

The highest mean value of nitrate $\left(67.88 \mu \mathrm{molL}^{-1}\right)$ was observed at St.III (El-Kabanon), this is may be due to disposal of treated and untreated sewage and industrial effluents. The lowest mean value $\left(2.07 \mu \mathrm{molL}^{-1}\right)$ was observed at St.II (El-Zaiytia), this is probably attributed to increase in plankton biomass, which feed on such nutrient and cause depletion in its concentration. On the other sector, the maximum nitrate level $\left(11.48 \mu \mathrm{molL}^{-1}\right)$ was recorded at St.VIX (Gemsa) and the minimum level $\left(5.27 \mu \mathrm{molL}^{-1}\right)$ was at St.IX (El-Zafrana).The annual average values varied between (19.73-6.08 $\mu \mathrm{molL}^{-1}$ ) at El-Kabanon and Gebl El-Zeet. Seasonally, the mean values recorded between 24.35 and $3.31 \mu \mathrm{molL}^{-1}$ were during summer and autumn, respectively. Compared to the other results, the nitrate values recorded during this study were remarkable high. The variations of nitrate content in the north-western sector were affected by different factors, the discharge of waste water through different outfalls such as the new treatment of wastewater of Suez city, the concentration of dissolved oxygen, water temperature, mixing and aeration, uptake by phytoplankton, nitrification and denitrification as well as decomposition from bottom sediments. 


\section{Water characteristics of the Western side along the Gulf of Suez (Red Sea) during (2014-2015)}

The mean values of $\mathrm{NH}_{3}-\mathrm{N}$ content varied between the maximum value $\left(43.15 \mu \mathrm{molL}^{-1}\right)$ recorded at St.III (El-Kabanon) and the minimum value $\left(3.24 \mu \mathrm{molL}^{-1}\right)$ recorded at St.I (Porttawfik). The maximum value may be indicator of the presence of pollutants of high activity and this is probably due to extensive discharge of different wastes.On the other hand, the mean values of $\mathrm{NH}_{3}-\mathrm{N}$ ranged between the highest value $\left(10.80 \mu \mathrm{molL}^{-1}\right)$ was observed at St.XII (Ras Shoker), this is may be due to increased human and industrial activities. The lowest value $\left(1.94 \mu \mathrm{molL}^{-1}\right)$ was observed at St.IX (El-Zafrana). The annual means fluctuated between the highest value $\left(23.98 \mu \mathrm{molL}^{-1}\right)$ at El-Kabanon and the lowest value $\left(4.31 \mu \mathrm{molL}^{-1}\right)$ at Ras Bakr. On the other hand, the maximum seasonal mean $\left(17.11 \mu \mathrm{molL}^{-1}\right)$ was during spring, this is attributed to the high evaporation rate, increased sewage and shipping activities. The minimum mean recorded $\left(3.99 \mu \mathrm{molL}^{-1}\right)$ during autumn may be due to utilization and oxidation of ammonia by plankton cells, which phytoplankton flourishing and exhausted ammonia as nitrogen source.

As shown in Tables $(3 \& 4)$, the $\mathrm{PO}_{4}-\mathrm{P}$ mean levels ranged between the highest level $\left(3.45 \mu \mathrm{molL}^{-1}\right)$ was recorded at St.III (El-Kabanon), and the lowest level $\left(0.93 \mu \mathrm{molL}^{-1}\right)$ at St.VI(Green-Island) where this station is far away from pollution sources. Annually, the maximum mean $\left(3.97 \mu \mathrm{molL}^{-1}\right)$ was at El-Zafrana and the minimum $\left(1.68 \mu \mathrm{molL}^{-1}\right)$ was observed at St.VI (Green-Island). Seasonally, the maximum mean $\left(3.88 \mu \mathrm{molL}^{-1}\right)$ was during winter season, while the minimum mean $\left(1.45 \mu \mathrm{molL}^{-1}\right)$ was during summer season. This result agrees with the result of Hamed et al. (2010).

Table (3): Mean concentrations of nutrient and phosphate salts $\left(\mu \mathrm{molL}^{-1}\right)$ in water samples collected from the Western sector of the Gulf of Suez during spring and summer (2014).

\begin{tabular}{|c|c|c|c|c|c|c|c|c|}
\hline \multicolumn{9}{|c|}{ Seasons } \\
\hline \multirow{2}{*}{$\begin{array}{l} \\
\text { St. }\end{array}$} & \multicolumn{4}{|c|}{ Spring (2014) } & \multicolumn{4}{|c|}{ Summer (2014) } \\
\hline & $\mathrm{NO}_{2}-\mathrm{N}$ & $\mathrm{NO}_{3}-\mathrm{N}$ & $\mathrm{NH}_{3}-\mathrm{N}$ & $\mathrm{PO}_{4}-\mathrm{P}$ & $\mathrm{NO}_{2}-\mathrm{N}$ & $\mathrm{NO}_{3}-\mathbf{N}$ & $\mathbf{N H}_{3}-\mathbf{N}$ & $\mathrm{PO}_{4}-\mathrm{P}$ \\
\hline I & 2.62 & 5.13 & 11.32 & 2.51 & 2.21 & 11.94 & 7.07 & 1.57 \\
\hline II & 2.59 & 5.94 & 14.47 & 2.61 & 2.49 & 17.64 & 7.39 & 1.08 \\
\hline III & 2.59 & 4.95 & 43.15 & 2.12 & 2.58 & 67.88 & 40.72 & 2.07 \\
\hline IV & 2.51 & 8.51 & 15.93 & 2.21 & 2 & 24.84 & 16.42 & 1.72 \\
\hline $\mathrm{V}$ & 2.82 & 7.65 & 16.31 & 2.31 & 1.56 & 20.79 & 11.13 & 2.07 \\
\hline VI & 2.44 & 18.09 & 10.91 & 2.31 & 2.18 & 20.79 & 4.21 & 0.93 \\
\hline VII & 2.09 & 6.98 & 13.02 & 2.36 & 0.97 & 14.89 & 4.21 & 1.03 \\
\hline VII & 2.38 & 5.22 & 11.88 & 2.22 & 0.79 & 16.25 & 5.35 & 1.13 \\
\hline IX & 1.78 & 6.62 & 2.97 & 4.77 & 2.22 & 5.27 & 4.27 & 2.02 \\
\hline $\mathrm{X}$ & 2.09 & 7.25 & 4.37 & 2.95 & 2.20 & 5.81 & 5.83 & 1.87 \\
\hline XI & 2.11 & 6.71 & 5.67 & 2.51 & 2.42 & 6.62 & 4.59 & 1.97 \\
\hline XII & 2.31 & 7.83 & 4.97 & 3.54 & 2.24 & 6.93 & 10.80 & 2.07 \\
\hline XIII & 2.22 & 5.40 & 6.26 & 3.09 & 2.31 & 5.27 & 8.26 & 2.22 \\
\hline XIV & 2.53 & 7.88 & 4.12 & 4.77 & 2.29 & 10.98 & 4.24 & 1.88 \\
\hline
\end{tabular}


Table (4):Mean concentrations of nutrient and phosphate salts $\left(\mu \mathrm{molL}{ }^{-1}\right)$ in water samples collected from the Western sector of the Gulf of Suez during autumn (2014) and winter (2015).

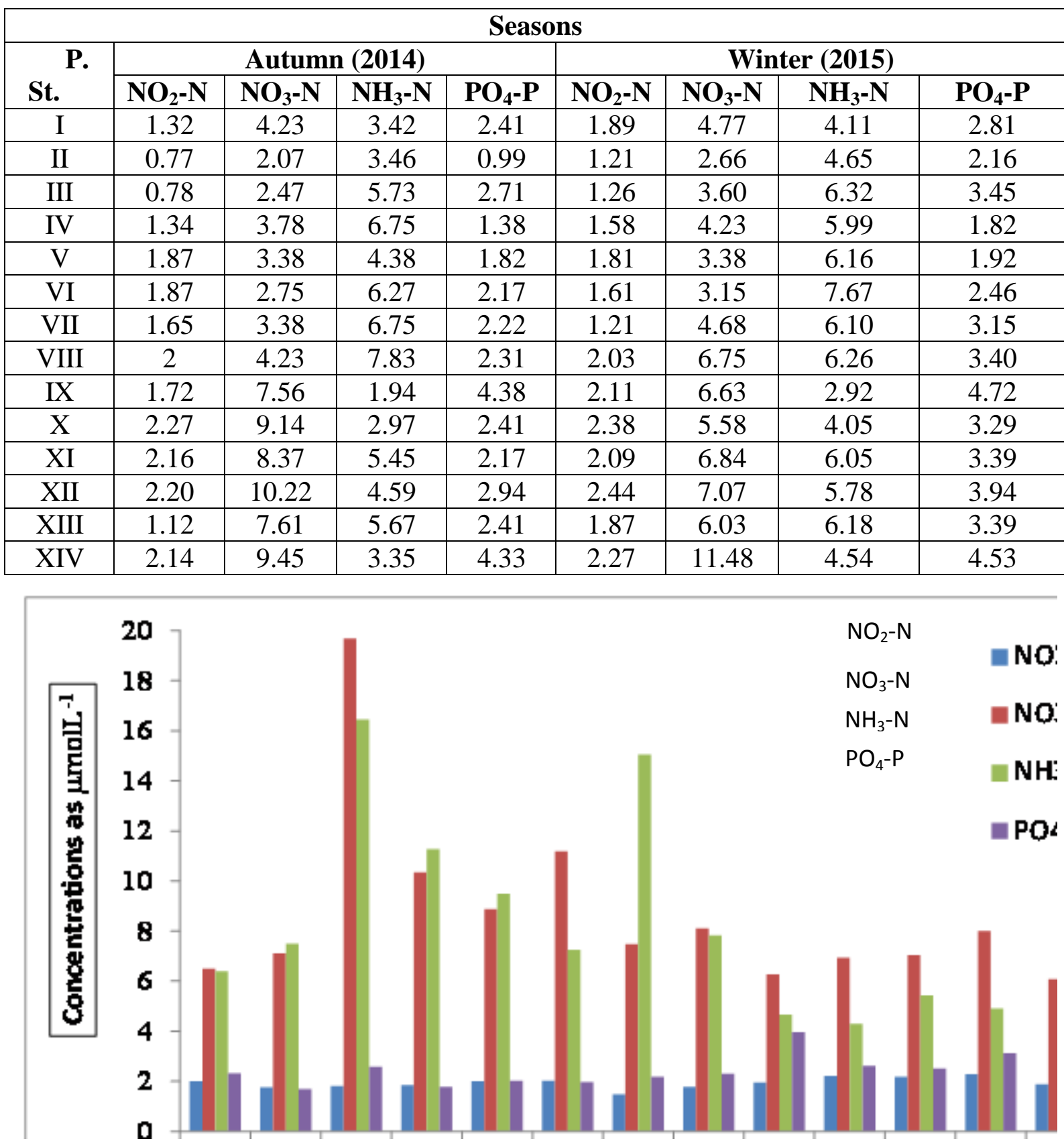

Fig. (3): Annual mean concentrations of nutrient and phosphate salts $\left(\mu \mathrm{molL}^{-1}\right)$ of water samples collected from the western sector of the Gulf of Suez.

The calculated ratios for $\mathrm{N}: \mathrm{P}$ are given in Table (5) for the northwestern and Table (6) for the southwestern sectors of the Gulf are more than that of Redfield ratio N:P $=16: 1$ (Redfield et al., 1963). Thus, phosphours is the limiting factor for phytoplankton growth in the study area.The level of nutrient salts indicated that the northwestern sector of Suez gulf is in the eutrophic state according to the standard levels reported by Franco (1983) (Table 8). 
101

Water characteristics of the Western side along the Gulf of Suez (Red Sea) during (2014-2015)

Table (5): Ranges, seasonal means, annual means and N:P ratio of nutrient salts of water samples collected from the northwestern sector of the study area during (20142015).

\begin{tabular}{|c|c|c|c|c|c|c|}
\hline \multirow[b]{2}{*}{ Parameter } & \multicolumn{6}{|c|}{ Seasons } \\
\hline & Values & $\begin{array}{l}\text { Spring } \\
(2014)\end{array}$ & $\begin{array}{c}\text { Summer } \\
\text { (2014) }\end{array}$ & $\begin{array}{c}\text { Autumn } \\
\text { (2014) }\end{array}$ & $\begin{array}{l}\text { Winter } \\
\text { (2015) }\end{array}$ & $\begin{array}{c}\text { Annual } \\
\text { mean }\end{array}$ \\
\hline \multirow{2}{*}{$\begin{array}{c}\text { Nitrite } \\
\left(\mu \mathrm{molL}^{-1}\right)\end{array}$} & Ranges & $2.01-2.87$ & $0.70-2.61$ & $0.74-2.03$ & $1.18-2.07$ & $0.70-2.87$ \\
\hline & $\begin{array}{c}\text { Seasonal } \\
\text { mean }\end{array}$ & 2.51 & 1.85 & 1.45 & 1.58 & 1.85 \\
\hline \multirow[t]{2}{*}{$\begin{array}{l}\text { Nitrate } \\
\left(\mu \mathrm{molL}^{-1}\right)\end{array}$} & Ranges & $4.80-18.1$ & $\begin{array}{l}11.89- \\
67.94\end{array}$ & $2.21-4.26$ & $2.62-6.79$ & $2.21-18.1$ \\
\hline & $\begin{array}{c}\text { Seasonal } \\
\text { mean }\end{array}$ & 7.81 & 24.35 & 3.31 & 4.19 & 9.89 \\
\hline \multirow[t]{2}{*}{$\begin{array}{l}\text { Ammonia } \\
\left(\mu \mathrm{molL}^{-1}\right)\end{array}$} & Ranges & $\begin{array}{l}10.84- \\
43.21\end{array}$ & $4.17-4.77$ & $3.20-7.88$ & $4.05-7.71$ & $3.20-43.21$ \\
\hline & $\begin{array}{c}\text { Seasonal } \\
\text { mean }\end{array}$ & 17.11 & 12.06 & 5.55 & 5.91 & 10.16 \\
\hline \multirow{2}{*}{$\begin{array}{l}\text { phosphate } \\
\left(\mu \mathrm{molL}^{-1}\right)\end{array}$} & Ranges & $2.06-2.67$ & $0.84-2.35$ & $0.83-2.47$ & $1.79-3.59$ & $0.83-3.59$ \\
\hline & $\begin{array}{c}\text { Seasonal } \\
\text { mean }\end{array}$ & 2.33 & 1.45 & 1.99 & 2.66 & 2.11 \\
\hline \multicolumn{2}{|c|}{ N:P ratios } & 11.77 & 26.39 & 5.18 & 4.39 & 10.38 \\
\hline
\end{tabular}

Table (6): Ranges, seasonal means, annual means and N:P ratio of nutrient salts of water samples collected from the southwestern sector of the study area during (20142015).

\begin{tabular}{|c|c|c|c|c|c|c|}
\hline \multirow[t]{2}{*}{ Parameter } & \multicolumn{6}{|c|}{ Seasons } \\
\hline & Values & $\begin{array}{l}\text { Spring } \\
\text { (2014) }\end{array}$ & $\begin{array}{c}\text { Summer } \\
(\mathbf{2 0 1 4})\end{array}$ & $\begin{array}{c}\text { Autumn } \\
(2014)\end{array}$ & Winter (2015) & Annual mean \\
\hline \multirow[t]{2}{*}{$\begin{array}{c}\text { Nitrite } \\
\left(\mu \mathrm{molL}^{-1}\right)\end{array}$} & Ranges & $\begin{array}{l}1.72- \\
2.57\end{array}$ & $2.18-2.46$ & $1.09-2.33$ & $1.80-2.51$ & $1.09-2.57$ \\
\hline & $\begin{array}{c}\text { Seasonal } \\
\text { mean }\end{array}$ & 2.17 & 2.28 & 1.93 & 2.19 & 2.14 \\
\hline \multirow[t]{2}{*}{$\begin{array}{c}\text { Nitrate } \\
\left(\mu \mathrm{molL}^{-1}\right)\end{array}$} & Ranges & $\begin{array}{l}5.34- \\
7.95 \\
\end{array}$ & $\begin{array}{l}5.21- \\
11.07\end{array}$ & $\begin{array}{l}7.50- \\
10.29 \\
\end{array}$ & $5.51-11.55$ & $5.21-11.55$ \\
\hline & $\begin{array}{c}\text { Seasonal } \\
\text { mean }\end{array}$ & 7.04 & 8.72 & 6.81 & 6.95 & 7.38 \\
\hline \multirow[t]{2}{*}{$\begin{array}{l}\text { Ammonia } \\
\left(\mu \mathrm{molL}^{-1}\right)\end{array}$} & Ranges & $\begin{array}{l}2.91- \\
6.29\end{array}$ & $\begin{array}{l}4.19- \\
11.08\end{array}$ & $1.82-5.73$ & $2.39-6.23$ & $1.82-11.08$ \\
\hline & $\begin{array}{c}\text { Seasonal } \\
\text { mean }\end{array}$ & 4.73 & 7.17 & 3.99 & 5.03 & 5.23 \\
\hline \multirow[t]{2}{*}{$\begin{array}{c}\text { phosphate } \\
\left(\mu \mathrm{molL}^{-1}\right)\end{array}$} & Ranges & $\begin{array}{l}2.38- \\
5.01\end{array}$ & $1.77-2.29$ & $2.12-4.50$ & $3.27-4.70$ & $1.77-4.70$ \\
\hline & $\begin{array}{c}\text { Seasonal } \\
\text { mean }\end{array}$ & 3.61 & 2.0 & 3.11 & 3.88 & 3.15 \\
\hline \multicolumn{2}{|c|}{ N:P ratios } & 3.86 & 9.09 & 4.09 & 3.65 & 4.68 \\
\hline
\end{tabular}




\section{Mohamed A. Hamed et al.}

The correlation coefficient between water characteristics in water samples collected from the Western sector of the Gulf during (2014-2015) was shown in Table (7).

Table (7): Correlation coefficient between water characteristics in water samples collected from the Western sector of the Gulf during (2014-2015).

\begin{tabular}{|c|c|c|c|c|c|c|c|c|c|}
\hline & $\mathrm{TC}^{\circ}$ & $\mathrm{S} \%$ & $\mathrm{pH}$ & DO & BOD & $\mathrm{NO}_{2}-\mathrm{N}$ & $\mathrm{NO}_{3}-\mathrm{N}$ & $\mathrm{NH}_{3}-\mathrm{N}$ & $\mathrm{PO}_{4}-\mathrm{P}$ \\
\hline $\mathrm{TC}^{0}$ & 1 & & & & & & & & \\
\hline$S \%$ & 0.12205 & 1 & & & & & & & \\
\hline $\mathrm{Ph}$ & 0.45667 & 0.592302 & 1 & & & & & & \\
\hline DO & -0.7365 & -0.08948 & -0.37912 & 1 & & & & & \\
\hline BOD & -0.3043 & -0.25869 & -0.0431 & 0.404499 & 1 & & & & \\
\hline $\mathrm{NO}_{2-\mathrm{N}}$ & 0.15010 & 0.309375 & 0.329474 & -0.09073 & -0.04991 & 1 & & & \\
\hline $\mathrm{NO}_{3}-\mathrm{N}$ & 0.38093 & -0.15794 & 0.313646 & -0.31493 & 0.171698 & 0.208268 & 1 & & \\
\hline $\mathrm{NH}_{3}=\mathrm{N}$ & 0.17253 & -0.43111 & 0.016666 & -0.16588 & 0.336865 & 0.360441 & 0.541559 & 1 & \\
\hline $\mathrm{PO}_{4}-\mathrm{P}$ & -0.4474 & 0.306393 & 0.282522 & 0.335418 & 0.218523 & 0.19526 & -0.17712 & -0.20557 & 1 \\
\hline
\end{tabular}

The present results matched with the results stated by Hamed and Said (2000) and Fahmy et al. (2005) who reported that the coast of northwestern sector of the Gulf of Suez (Suez Bay) is richer in nutrient salts followed in decreasing order to southwestern sector of the Gulf, due to the intense discharge of industrial and domestic wastes in waters of the northwestern sector. As shown in Table (8), the results of physico-chemical parameters are agreed with other findings by Hamed et al. (2010) at the northern Red Sea (Suez Bay) and Soliman et al. (2015) at Suez Canal. Moreover, the results of nutrient salts are higher than the results found by Abdelmony and El-Moselhy (2015) and Nassar et al. (2016) at the northern Red Sea, also Soliman et al. (2015) at Suez Canal (except for nitrite).

Table (8): Comparison between levels of physico-chemical parameters and nutrient and phosphate salts in the present study with those of neighboring regions.

\begin{tabular}{|c|c|c|c|c|c|c|c|c|c|c|}
\hline Area & $\begin{array}{l}\text { Temp. } \\
{ }^{\circ} \mathrm{C}\end{array}$ & $\mathrm{Se}_{\mathrm{b}}$ & PH & $\begin{array}{c}\mathrm{DO} \\
\mathrm{mgO}_{2}^{-} \mathrm{L}^{3}\end{array}$ & $\begin{array}{c}\text { BOD } \\
\mathrm{mgO}_{1} \mathrm{~L}\end{array}$ & $\begin{array}{l}\mathrm{NO}_{2}-\mathrm{N} \\
\mu \mathrm{molL}-1\end{array}$ & $\begin{array}{l}\mathrm{NO}_{2}-\mathrm{N} \\
\text { pmoll-4 }\end{array}$ & $\begin{array}{l}\mathrm{NH}_{3}-\mathrm{V} \\
\underset{1}{\mathrm{Nmoll}}\end{array}$ & $\begin{array}{l}\mathrm{PO}_{4}-\mathrm{N} \\
\text { pmoll }\end{array}$ & Refereace \\
\hline $\begin{array}{l}\text { Northwestern } \\
\text { sector of the Gulf }\end{array}$ & $\begin{array}{l}18.40- \\
30.10\end{array}$ & $\begin{array}{l}39.90- \\
40.51\end{array}$ & $\begin{array}{l}8.08- \\
8.39\end{array}$ & $\begin{array}{l}4.28- \\
10.41\end{array}$ & $\begin{array}{l}1.53- \\
7.04\end{array}$ & $\begin{array}{l}0.77 \\
2.82\end{array}$ & $\begin{array}{l}2.07- \\
67.88\end{array}$ & $\begin{array}{l}3.24- \\
43.15\end{array}$ & $\begin{array}{l}0.93- \\
3.59\end{array}$ & \multirow[b]{2}{*}{ Present study } \\
\hline $\begin{array}{l}\text { Southwestern } \\
\text { sector of the Gulf }\end{array}$ & $\begin{array}{l}17.70- \\
33.30\end{array}$ & $\begin{array}{l}40.45- \\
40.88\end{array}$ & $\begin{array}{l}8.16- \\
8.37\end{array}$ & $\begin{array}{l}4.36- \\
10.71\end{array}$ & $\begin{array}{l}1.53- \\
6.73\end{array}$ & $\begin{array}{l}1.12- \\
2.53\end{array}$ & $\begin{array}{l}5.27- \\
11.48\end{array}$ & $\begin{array}{l}1.94- \\
10.80\end{array}$ & $\begin{array}{l}1.87 \\
4.77\end{array}$ & \\
\hline $\begin{array}{l}\text { Northwestern } \\
\text { sector of the Guif }\end{array}$ & $\begin{array}{l}19.0- \\
28.0\end{array}$ & $\begin{array}{l}41.02- \\
42.30\end{array}$ & $\begin{array}{l}8.06- \\
8.36\end{array}$ & $\begin{array}{l}8.20 \\
10.95\end{array}$ & - & $\begin{array}{l}0.70- \\
4.95\end{array}$ & $\begin{array}{l}4.64- \\
20.85\end{array}$ & $\begin{array}{l}3.12- \\
16.70\end{array}$ & $\begin{array}{l}0.32- \\
3.04\end{array}$ & $\begin{array}{l}\frac{\text { Hamed et al. }}{2010} \text { and } \\
\text { Hussein, } 2011\end{array}$ \\
\hline Gulf of Saez & - & $\begin{array}{l}42.10= \\
43.27\end{array}$ & $\begin{array}{l}7.62- \\
7.65\end{array}$ & $1.94-2.87$ & $151-250$ & 0.0 .188 & $0.01-8.02$ & $\cdot$ & $\begin{array}{l}15.0= \\
61.0\end{array}$ & $\frac{\text { Emara et al. }}{2013}$ \\
\hline Secz Canal & $\begin{array}{l}14.89 \\
29.24\end{array}$ & $\begin{array}{l}29.85- \\
44.99\end{array}$ & $\begin{array}{l}7.51 \% \\
8.18\end{array}$ & $\begin{array}{l}5.56- \\
10.72\end{array}$ & $\begin{array}{l}1.36- \\
7.95\end{array}$ & $\begin{array}{l}0.05- \\
16.83\end{array}$ & $\begin{array}{l}1.04- \\
25.33\end{array}$ & $\begin{array}{l}0.26- \\
22.12\end{array}$ & $\begin{array}{l}0.03- \\
2.11\end{array}$ & $\frac{\text { Soliman ef al. }}{2015}$ \\
\hline Gulf of Suez & $\begin{array}{l}19.10- \\
31.20\end{array}$ & $\begin{array}{l}39.70- \\
41.70\end{array}$ & $\begin{array}{l}7.60- \\
8.44\end{array}$ & - & - & - & - & $\cdot$ & $\cdot$ & $\frac{\text { EI-Metwally; }}{2015}$ \\
\hline Nortbern Red Sea & $\begin{array}{l}17.96- \\
32.56\end{array}$ & $\begin{array}{l}40.02- \\
42.32\end{array}$ & $\begin{array}{l}7.78- \\
8.21\end{array}$ & $6.05-8.05$ & $\begin{array}{l}0.73- \\
4.15\end{array}$ & $\begin{array}{l}0.07 \\
0.12\end{array}$ & $0.43-3.17$ & $\begin{array}{l}2.41= \\
12.56\end{array}$ & $\begin{array}{l}0.08- \\
0.38\end{array}$ & $\begin{array}{l}\text { Abdelmony and } \\
\text { El-Moselhy; } \\
\frac{2015}{}\end{array}$ \\
\hline Northera Red Sea & $\begin{array}{l}16.50- \\
27.50\end{array}$ & - & $\begin{array}{l}7.75- \\
8.27\end{array}$ & $\begin{array}{l}3.35- \\
10.39\end{array}$ & - & $\begin{array}{l}0.028- \\
0.408\end{array}$ & $\begin{array}{l}0.170- \\
1.205\end{array}$ & $\begin{array}{l}0.067 \\
1.248\end{array}$ & $\begin{array}{l}0.007- \\
0.413\end{array}$ & $\begin{array}{c}\text { Nassar ef af. } \\
2016\end{array}$ \\
\hline Oligotropbic leved & & & & & & & 0.51 & 0.51 & 0.05 & $\begin{array}{l}\text { Skrivanic and } \\
\text { Strin, } 1982\end{array}$ \\
\hline Eutrophic level & & & & & & & 4.02 & 2.02 & 0.3 & Franco, 1983 \\
\hline
\end{tabular}




\section{Water characteristics of the Western side along the Gulf of Suez (Red Sea) during (2014-2015)}

\section{Conclusion}

Water characteristics of the Gulf of Suez show constant seasonal and local trends over the year; this is attributed to the effect of different water flows from the Red Sea and Suez Canal. Also, the Gulf of Suez suffered from different considerable source of land based and sea based activities; waste discharging from shipping transit, untreated domestic sewage from Suez City and other tourist villages, oil and industrial effluents from refineries and petrochemical companies and fish processing activities. These sources are concentrated in the northern part of the Gulf. The southern part of the Gulf is affected mainly by seepage from oil fields, effluents from oil rigs, waste discharging from tankers passing through the Gulf of Suez and different fishing activities.

The present results indicated that the following:

1. The maximum concentration of nutrient salts was recorded in northwestern sector, this is due to waste discharging from shipping transit, untreated domestic sewage from Suez City and other tourist villages, oil and industrial effluents from refineries and petro-chemical companies and fish processing activities.

2. the area of investigation can be divided into two regions Suez Bay region as an eutrophic water (high productivity) and the part of the Gulf as going southward to Gemsa, which has considered as oligotrophic water (low productivity).

3. the maximum N:P ratio (26.39) was recorded during summer at the northwestern sector of the Gulf.

4. the maximum seasonal values of nutrient salts was recorded in spring and summer season, this is attributed to increase human and shipping activities and extensive discharge of treated and untreated sewage.

\section{REFERENCES}

Abdelmongy, A.S. and El-Moselhy, K.M.(2015). Seasonal variations of the physical and chemical properties of seawater at the Northern Red Sea, Egypt. Open J. Ocean. Environ. Develop., 6 (1): 49-73.

APHA , American Public Health Association (2005).Standard methods for the examination of water and wastewater, $21^{\text {th }}$ Edition, Washington DC, USA.

ANON (1975). Environmental control and public health, water analysis, standards and treatment, Eyre and Spohiswoode Ltd., ECPH.Pp. 131.

Barakat, M.A.; El-Sayed, E. and Ouf, E.A. (2009). Evaluation of drinking water quality in delta of Egypt. Egypt. J. Petrol., (1):81-92.

Beltagy, A.I. (1983). The distribution of some trace elements in diatomaceous pelagic zone from the southern ocean. Bull. Inst. Oceanogr. Fish., ARE, 7 (3): 343-351 .

Cole, G.E.(1979). Text book of limnology, $2^{\text {nd }}$ Eds. C. V. Company.P. 426.

Emara, M.M.; Farid, N.A.; El-Sabagh, E.A.; Ahmed, O.E. and Kamal, E.M. (2013). Pysicochemical study of surface water in the Northwestern Gulf of Suez. Egyp. J. Chem., 56: $345-356$.

El-Metwally, M.E. (2015). Monitoring of heavy metals pollution in the Egyptian Red Sea coast and response of marine organisms. Ph.D., Thesis. Faculty of Science.Mansours University,P. 275.

Fahmy, M.; Sheriadah, M.; AboulSoued, A.; Abdel Rahman, S. and Shindy, M. (2005). Hydrogen and chemical characteristics of the coastal water along the Gulf of Suez. Egyp. J. Aquat. Res., 31: 1-14.

Franco, P. (1983). Fattori influent sullaproguctiviaprimaria dell Adriatico Settentrionale. Proc. Int. Conf. Problems of the Adriatic Sea, Trieste. Pp. 155-174. 


\section{Mohamed A. Hamed et al.}

Girgis, A.M. (1980). Investigation of level and effects of pollutants on saline lakes and littoral marine environments. Part II: Hydrography of Lake Qarun. Scientific Report, Acad. Sci. Res. \& Tech., Inst. Oceanogr. \& Fish., P. 166.

Hamed, M.A. (1996). Determination of some micro-elements in aquatic ecosystems and their impact to the efficiency of aquatic life. Ph. D. Thesis, Fac. Sci., Mansoura Univ.

Hamed, M.A. and Said, T.O. (2000). Effect of oil pollution on the water quality of the Gulf of Suez. Egypt J. Aquat. Biol. Fish., 4: 161-178.

Hamed, M.A.; Soliman, Y.A.; Khodir, A.E.; Soliman, A.H.; El-Agroudy, N.A. and Hussein, F. (2010). Physio-chemical characteristics of Suez Bay water during 2006-2007. Egypt. J. Aquat. Biol. \& Fish., 14 (1): 43-57.

Hamed, M.A.; Mohamedein, L.I. and El-Sawy, M.A. (2012). Physico-chemical analysis and speciation of heavy metals in wastewater and sediment samples from the Suez Province in Egypt. J. Environ. Chem. and Ecotox.,4 (12): 222-228.

Hussein, F. (2011).Study of oil pollution at the northern part of Suez Gulf. M.Sc. Thesis, Chem. Depart., Fac. Sci., Suez Canal Univ.

Khalil, W.K.; Abdel-Gawad, F.K.; Belattar, N.; Senator, A. and Abdel-Wahhab, M.A. (2011). Protective effects of Nigella sativa extract against chromium vi-induced genotoxicity in Nile Tilapia exposure. (Oreochromis niloticus) and Zebrafish (Danio rerio).Glob. Vet., 7 (3): 283-293.

Khalil, M.A.; Beltagy, E.A.; El-Shouny, W.A.; Abo El-Naga, E.H.; El-Shenawy, M.A. and Kelany, M.S. (2014).Seasonal bacteriological and physico-chemical analysis of Lake Temsah, Ismailia, Egypt. Life Sci. J., 11(10): 9-17.

Maiyza, L.A. (1988). Evaporation of coastal water in the NW Red Sea. Bull. Inst. Oceanogr. \& Fish., A.R.E., 14(1): 75-80.

Nassar, M.Z.; Mohamedein, L.I. and El-Sawy, M.A. (2016). Seasonal variations of phytoplankton and nutrients in the Egyptian Harbors of the Northern Red Sea. Int. J. Mar. Sci., 6(8): 1-17.

Parsons, T.R.; Matia, Y. and Lalli, C.M. (1984).Determination of chlorophylls and total carotenoids: spectrophotometric method, a manual of chemical and biological methods for seawater analysis. Pergamun Press, New York. Pp. 101-104.

Ramanathan, N.; Padmavathy, P.; Francis, T.; Athithian, S. and Selvaranjitham, N. (2005). Manual on polyculture of tiger shrimp and carps in freshwater. 1.Tamil Nadu Veterinary and Animal SciencesUniversity, Fisheries College and Research Institute, Thothukudi, P. 161.

Redfield, A.C.; Katchum, B.H. and Richards, S.A. (1963). The influence of organisms on the composition of sea water. In: the sea. Vol. 2, M.N. Hill (Ed.) John Wiley and Sons, New York. Pp. 26-77.

Skrivanic, V. and Strin, J. (1982).Basic physical, chemical and biological data reports. R.V. Mohorov ICIC Adriatic cruises, 1974-76. Hydrographic Inst., of the Yugoslav Navy Split., P. 175.

Soliman, G.F. (1999). Simulation of water circulation in the Suez Bay and its hydrographic features during winter and summer.The $6^{\text {th }}$ Conf. of the Environ. Port. Is a Must. Nat. Oceanogr. \& Fish., Euro-Arab Cooperation Center, Inter. Sci. Assoc. \& Soci. Fund for Development. Pp. 400-433.

Soliman, Y.A.; El-Kholy, N.G.; Hamed, M.A.; Salman, A.A. and Zaghloul, G.Y. (2015). Physico-chemical studies of Suez Canal water from Port-Said to Suez for its evaluation and protection. Blue Biotechnol. J., 3(1): 143-158.

UNESCO/WHO (1973).Water quality surveys. A guide for the collection and interpretation of water quality data, 23: 350 . 


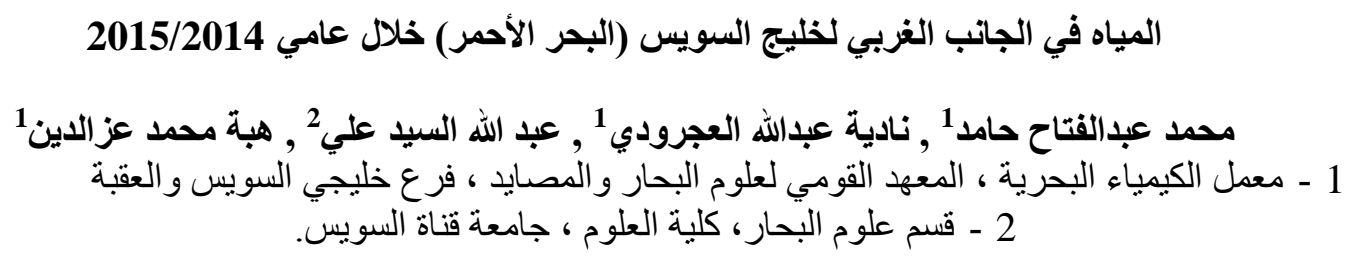

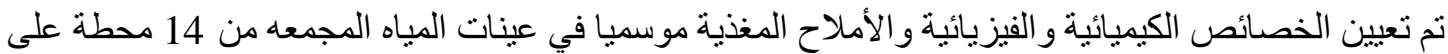

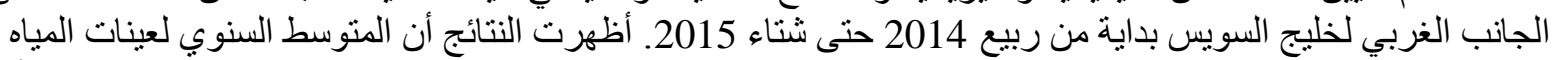

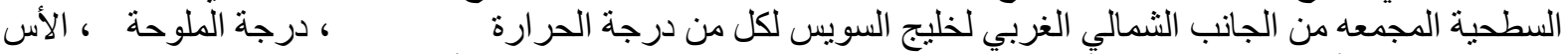

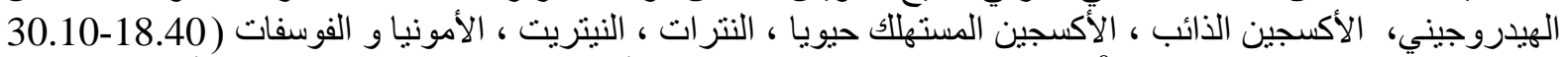

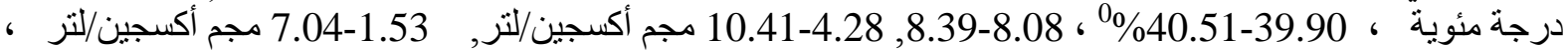

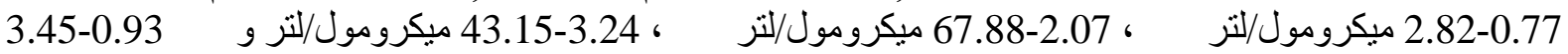

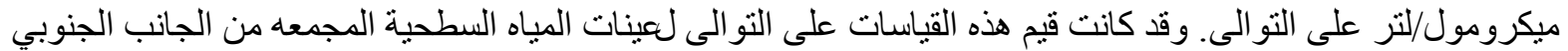

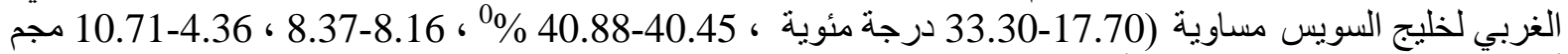

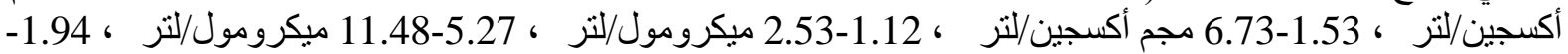

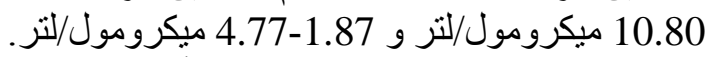

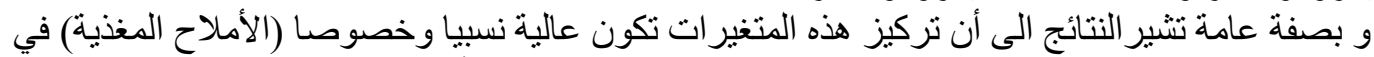

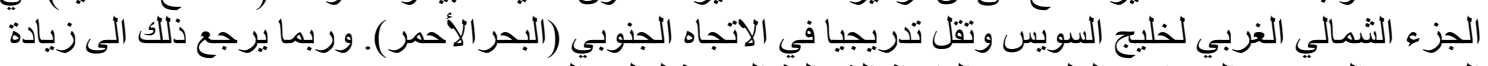

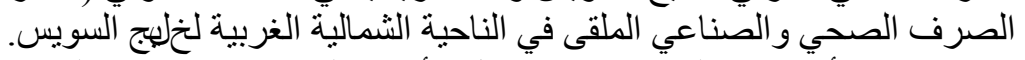

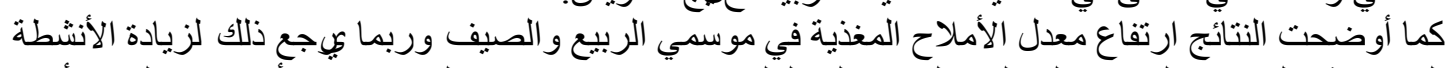

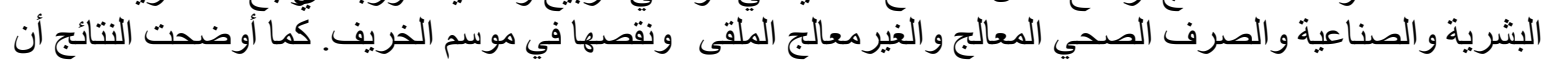

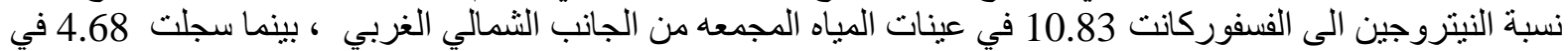

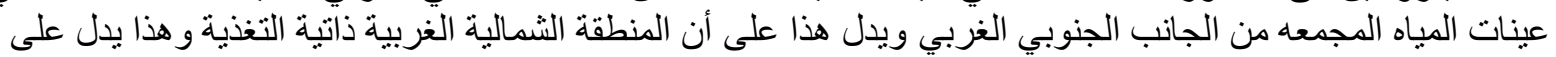
ما تعانيه المنطقه من زيادة الصرف الصحي الملقى و المخلفات الصناعية. 